\title{
The Business of Lobbying in the European Union
}

\section{Evarist Beqiri}

Phd Candidate, Faculty of Law, University of Tirana

Saimir Shatku

Phd Candidate, Faculty of Law, University of Tirana

Mimoza Sadushaj

Doi:10.5901/ajis.2015.v4n1p445

Phd Candidate, Faculty of Law, University of Tirana

\section{Abstract}

The purpose of this paper is to give an overview of the developments in the European lobbying arena and its main actors. The thesis is based on the latest studies in this field. Along with the dynamic development of the European institutions, the number of interest organizations at European level increased. Besides the EU institutions, the private actors operating at the European level can be divided into two main groups: the group that protects business interests and the group that does not protect them. After the first direct elections for the European Parliament and the adoption of the Single European Act, an increase of lobbying activities in EU is noticed.

Keywords: European Union, Lobbying main actors, European arena, Lobbying firms, Lobbying activities;

\section{Introduction}

Along with the dynamic development of European institutions, the number of interest organizations at European level increased (Eising, 2001; Kohler-Koch, CONZELMANN, 2004).

In the EU arena business groups are widely predominant numerically and politically as well (Jordan, 1998; KohlerKoch, CONZELMANN, 2004). Therefore, they have been analysed in the academic literature, but as implied in the title of Pedler's book "Changes in the Arena", the situation is changing in recent decades: "The players who have clearly gained influence since the first case study are non-governmental organizations, otherwise known as the civil society "(Pedler, 2002). (Charad, 2004)

Greenwood goes further and requires an explanation why the civil society is engaged in the EU political system: "A major factor is the part played by the European Commission, through its role in developing policy initiatives, and its need to work with external interests in pursuit of European integration. [...] The origins of a number of groups, particularly in the areas of public interest, trace back directly to the Commission departments which are looking for allies. These groups are supported through functions that are delegated to them by the Commission" (Greenwood, 2003).

Greenwood describes the relationship between interest groups and EU institutions as interdependent which explains the rise of interest groups, while the powers of EU expand.

"Decision-making in EU, at least in the most traditional areas of policy-making, is a dynamic process which requires collaboration and competition from actors of different institutions and stakeholders in order to provide them with the results they want. Decision-making is not a monopoly of institutional actors. Actors from private and public interest groups can be influential in shaping the decisions, either through formal consultation or acting as sources of information, expertise and mediation among other actors who often are institutional" (Warleigh, 2000, 2003).

\section{The variety of interest in the EU}

Brussels is now complete with informal and formal networks of lobbying. Informally, public affairs' specialists with the same nationality or language gather together in certain bars in the so-called European neighborhood (Quartier Européen). Other informal networks are based on education such as the alumni network of ENA school (École Nationale d'Administration) which involves French officials, politicians and lobbyists, or professional ties such as the group Ravenstein which includes directors of companies for large public works. 
Many formalized associations have emerged in the arena such as Society of European Affairs Professionals (SEAP), Public Affairs Professionals (AEP), the European Federation of Public Affairs and Lobbying (FELP) or the European Centre for Public Affairs Brussels (ECPAB). The courses offered recently and the intensive programs are expensive, but they are widely recognized by the lobbyists for their quality. Faculties include not only academics and professional lobbyists but also European officials and members or ex-members of the European Parliament. (Lehmann \& Bosche, 2003)

One of the major goals is to improve interstate communication and reduce national divisions that still exist. Also, there are programs from which you get a degree, for instance Master in Business Administration and specializations such as "Lobbying and business representatives."

British, Dutch and American firms were the first to recognize the potential importance of direct representation in Brussels. Movements of Americans can be seen as an acknowledgment of the importance of EU. According to authors like Coen the beginnings of lobbying are focused on member states and the Council of Ministers. (Coen, 2002) With the expansion of the spectrum of policies that would be subject to co-decision and qualified majority voting in the Council, British and Dutch conglomerates like Shell, BP, ICl and Philips followed the path of the Americans by being rapidly internationalized. The emergence of these conglomerates overwhelmingly Anglo-Saxon encouraged other European gigantic firms like Fiat, Olivetti or Daimler-Benz to participate actively in the European debate. These firms exercised a strong influence on French and German firms which were still focused on national associations. However, Koen emphasizes that early objectives of firms such as Philips, Olivetti or Fiat were to create a protected European market. With their long tradition of direct lobbying, British firms tended to develop a dual lobbying strategy at national and European level. Unlike their German and Dutch counterparts which considered their governments and their national associations as a complementary and safe option to influence EU, the dual strategy of British firms is often directed towards the Europeanization of a government which was often conservative regarding the European perspective. Today French business is as active as the British one, by representing about $9 \%$ of offices dealing with European affairs in Brussels. In general, British and American firms welcomed the arrival of large French firms in Brussels because these firms gave their alliances a higher degree of legitimacy. (Lehmann \& Bosche, 2003)

In Germany, business has traditionally had a high degree of trust in government and national channels that were used to influence the EU policy process. German business is characterized by a broad consensus regarding the general direction of European integration. While direct lobbying in the EU increased by German firms, national associations have started to direct their resources to EU lobbying, and many of them such as Verband der Chemischen Industrie have representatives in Brussels. At the same time, German firms have been somewhat reluctant to come out of their corporatist system that provides reliable tools to influence the federal government and the European federation. However, German firms have learned to lobby within the industrial forums of Brussels with firms such as BMW, Hoechst, Bertelsmann, BASF, Bayer, Bosch, Daimler Benz and Siemens.

In conclusion, the degree of Europeanization of business interests still varies according to specific issues and lobbying traditions in the Member States. Until now, there has been a trend towards direct lobbying strategy, which is summarized in certain specifics according to the sectors and ad-hoc alliances based on certain issues. Firms that find their position threatened nationally, feel the need to become a member of a Eurogroup. (Coen, 2002) On the other hand, where member states retain primary authority and responsibility, interests have less reason to be organized at European level. Achievements of the Common Market project, the important role that Member States play in the implementation and enforcement of European rules and the principle of subsidiary, all lead in the continuity of maintaining the authority of the member states. (Lehmann \& Bosche, 2003)

The variety of interests that with a stake in the European public affairs is vast. It includes firms, professions, employers and labour groups, consumers, causes, social/community, civil and environmental interests, at European, national and sub-national level of organization, and territorial interests themselves, such as regional and local government. They act alone or collectively, in EU public affairs. Despite the fact that the number of individual lobbying companies increased in the past decade and also the number of informal structures that bind them, they are still formal collective entities that dominate the representation of interests in EU. Formally constituted interests associations geared towards towards political action at EU level exist for: (Greenwood, 2007, 9)

- multinational firms and national interests of business-wide interest associations through to natural sausage casing producers and national associations of social entrepreneurs;

- Accountants, doctors, engineers and lawyers, through to handwriting analysts and fish pathologists, chimney sweeps and beauticians;

- mine workers to fairground hands; 
- aquariums trustees to cyclists; bird conservationists to specialist bird ringers; mainstream consumers to beerdrinking enthusiasts;

- regions endowed with legislative authority, and big city municipalities, through to networks of wine growing regions;

- environmental and animal welfare campaigners through to those campaigning for health enhancing physical activity;

- international human rights organizations through to cluster of "alternative" networked activists with a website;

- Catholic charities to humanist organizations ;

- Young people to older women;

- General organizations of citizens through to specialist drug helpline agencies.

There is no definitive list of the number and different types of players active in EU interest representation, partly because of the complexity involved in identifying and classifying players. A number of informal network structures link players together, but there is no way to do a head count of these. (Greenwood, 2007, 10)

Lobbyists in the European Union are generally divided into three categories: industrial associations, nongovernmental organizations (NGOs) / interest groups and regional representation. It is not easy to build a map of effective lobbying presence in the European capital. In fact today five thousand accredited lobbyists have ongoing access to Parliament. Five thousand accredited lobbyists for 732 members of Parliament are equivalent to seven lobbyists for each of them. According to CEO, which is a Dutch non-profit research group, 70\% of the 15 thousand present lobbyists represent the interests of big industry. Apart from this, we should take into consideration the role of powerful industrial associations such as ERT (Industrialists Round Table), Union of Industries of the European Communities (UNICE) and the European Services Forum (ESF). (Bennardo \& Farella \& Oretano \& Savazzi \& Poletti \& Di Staso, 2010)

There are about 815 European and international federations, more than 200 representative offices of regional and local authorities, more than 350 companies represented directly, about 150 consultancy offices and many other dealing with community problems in addition to Chambers of Commerce, industrial and sectorial federations and citizens associations. By adding to such lobbies multiple representation of states and institutional ones, the number of people that influence the community system would be about 55.000 (fifty-five thousand) versus 30.000 (thirty thousand) officials of community institutions. So, the proportional ratio is almost 2:1.

The total number of people who act with a different title, directly or indirectly in the system, including officials and accredited journalists (more than 1000 (one thousand), a community which is larger than the one in Washington DC), would be approximately about 150.000 (one hundred fifty thousand persons). (Bennardo \& Farella \& Oretano \& Savazzi \& Poletti \& Di Staso, 2010)

During the research, a monthly increase from 50 to 100 units has been noticed for each of the categories listed below, except for the category "other organizations", for which it was recorded a slight decrease in the number of accredited representative offices. (Bennardo \& Farella \& Oretano \& Savazzi \& Poletti \& Di Staso, 2010)

$\begin{array}{lc}\text { Consultancy associations specialized in legal studies } & \mathbf{1 5 9} \\ \text { which perform lobbying activities in the EU institutions } & \\ & 15 \\ \text { Law firms } & 81 \\ \text { Society for public affairs consulting } & 35 \\ \text { Consultancy on public affairs } & 28 \\ \text { Other similar organizations } & \\ & \\ \text { "Internal lobbyists" and categories associations which deal with lobbying activities } \mathbf{1 4 6 1} & 368 \\ \text { Enterprises } & 836 \\ \text { Categories associations } & 73 \\ \text { Syndicates } & 184 \\ \text { Other similar organizations } & \end{array}$

NGOs and study centers (think-tanks) ${ }^{1} \quad \mathbf{8 0 5}$

Non-governmental organizations and their associations 613

$\begin{array}{ll}\text { Think tanks } & 87\end{array}$

Other similar organizations 105

$\begin{array}{ll}\text { Other organizations } & 327\end{array}$

Academic organizations and their associations 90

Representatives of religions, churches and secular communities 9

Associations of public administration 46

Other similar associations 182 
First of all, we should make a distinction between the so called lobbying firms and lobbying organizations: the first includes individuals who develop their activity directly, or legal persons who use third parties on behalf of a client different from themselves, and the latter consists of entities (companies, associations, etc) which benefit from people who perform lobbying activities on behalf of the entity itself. These lobbying firms can be private independent companies or subsidiary of multinational groups. The most quoted specialists are Hill \& Knowlton, Burston Marsteller, Apco Worldwide, KreabGavinAnderson, WeberShandwick and InterelCabinetSteward. (Bennardo \& Farella \& Oretano \& Savazzi \& Poletti \& Di Staso, 2010)

There are 30 Belgium law firms. The English-speaking law firms located in Brussels include 49 firms from a total of 127. The presence of Italian law firms in Brussels has increased in recent years and it is in good position compared to France and Germany.

In addition, some Italian law firms have created a specific cell for the relationships with community institutions, which aims to inform their clients on community projects and the decisions of the Court of Justice of the European Community. The main presence of the registered law firms is represented by German and Spanish. However, some differences will be noticed if the registry is analyzed. In the description of the German law firms' activity, information related to billing is not updated; while in the case of Spanish firms, the figures are updated and the description of the performed activities is more complete. (Bennardo \& Farella \& Oretano \& Savazzi \& Poletti \& Di Staso, 2010)

Until today, 613 non-governmental organizations and their associations are registered in the register of interest representatives, 87 think tanks and 105 organizations of a similar nature. They all make a total of 805 representatives of interest that are included in the III category of the register. NGOs and research centers are involved in the decision making process as the voice of the civil society. The only community institution in which they are represented is in the European Parliament, thus creating the genesis of the so-called "democratic deficit". (Bennardo \& Farella \& Oretano \& Savazzi \& Poletti \& Di Staso, 2010)

Non-governmental organizations (NGOs) seek to influence community institutions by drafting "White Books" with specific official proposals for a certain topic, and "Green Books", or rather documents that precede official negotiations. In addition, they perform consultancy actions and can be called by decision-makers. Naturally, the biggest, richest and most popular NGOs possess more resources for their own stocks of lobbying and advocacy, and they make more investments in studies and scientific researches.

Tamsin Rose, former Secretary General of the European Public Health Alliance, an international non-profit association registered in Belgium, whose mission is to "promote and protect the health of persons resident in Europe and to support greater participation of citizens in shaping policies pertaining health to the European level", has outlined the role of NGOs in lobbying in this way:

1. Monitoring the life of institutions and the emergence of new policies;

2. Analyzing the impact of regulations on the groups' own interest;

3. Providing information regarding the main elements of their own proposals and to explain in what way they are processed;

4. Increasing the awareness of their members regarding the impacts and effects of policies and legislation;

5. All inclusion encouraging debate and exchange of ideas on the role of lobbying;

6. Consulting different organizations - particularly those directly involved by the norm - collecting views;

7. Asking decision makers and other stakeholders to provide evidence in order to support their position;

8. Providing instruments of action, for example meetings, letters, collection of firms;

9. Representing different voices of civil society by making them visible in the media;

10. Assessing the implementation of actions that are performed. (Bennardo \& Farella \& Oretano \& Savazzi \& Poletti \& Di Staso, 2010)

Think tanks are institutions and foundations that deal with the study of a topic and elaborate new ideas and original proposals. In the special section of the European registry, there are 87 think tanks, though in reality many organizations registered as NGOs are self-defined as think tanks for example Amnesty International. Some of the most active and prosperous think tanks are Friends of Europe, Security \& Defense Agenda (SDA), which was established in 2003 and funded by arms manufacturers like Lockheed Martin, BAE Systems, and TechCentralStation, which was supported economically by automobile and fuel manufacturers such as General Motors and Exxon Mobile, which has come to light, especially through the battle against exaggerated characteristic alarms about global warming.

Researchers have divided these organizations into four main categories: academic think tanks which are focused on an academic-type research; advocacy think tanks which make proposals pursuant to their values ; research institutes, contracted by the governments, industries and agencies; foundations and think tanks established by one political party. 
(Boucher \& Royo \& Lamy, 2006, 160)

As it turns clear from this division, the main problem of these organizations is to maintain a thought autonomy: having the client and the donator actually means having limited autonomy in analysis and having the tendency to "satisfy" the demands of other people. The same problem occurs even when the clients are the European institutions, above all in the case when researches are openly against community policies.

Taking into consideration the fact that there are 1200 active think tanks in the European territory, it is obvious that the number of those that are registered is ridiculous. In April 2009, given the low participation in the registry, the anti-fraud commissioner of that time Siim Kallas invited publicly these think tanks to enroll in the section dedicated to them, by clarifying that the European definition of lobbying "includes all activities taken forward with the objective of influencing the policy formulation and decision-making process of the community institutions."

In reality the issue is still open, even within the think tanks the thoughts on the necessity of registration are not unanimous. Grounds for refusal are different such as a very wide definition of lobbying, the lack of a special interest to promote it and the need to take a joint decision. An American study "The Global Go-to think tanks", which was issued on January 21, 2010, classifies the best 40 think tanks in Western Europe. From these 40 think tanks, only 6 of them are present in the registry, while 4 of them are registered as NGOs. So, it is clear that there are a series of problems related to the registration of these think tanks, problems which come directly from the lack of a unanimous definition of lobbying. (Bennardo \& Farella \& Oretano \& Savazzi \& Poletti \& Di Staso, 2010)

\section{Conclusions}

Lobbyists in the European Union are generally divided into three categories: industrial associations, non-governmental organizations (NGOs) / interest groups and regional representation.

Along with the dynamic development of European institutions, the number of interest organizations at European level increased. The players who have clearly gained influence since the first case study are non-governmental organizations, otherwise known as the civil society. Decision-making in EU, at least in the most traditional areas of policymaking, is a dynamic process which requires collaboration and competition from actors of different institutions and stakeholders in order to provide them with the results they want.

In EU there are informal and formal networks of lobbying. With their long tradition of direct lobbying, British firms tended to develop a dual lobbying strategy at national and European level. Unlike their German and Dutch counterparts which considered their governments and national associations as a complementary and safe option to influence EU, the dual strategy of British firms often directed towards the Europeanization of a government which was often conservative regarding the European perspective.

Still, it is clear that there are a series of problems related to the registration in the lobby registry, especially regarding the registration of the think-tanks.

Finally, we could say that the relationship between interest groups and EU institutions is interdependent which explains the rise of interest groups, while the powers of EU expand.

\section{References}

Olldashi (Boçi) E., "Hyrje mbi teoritë e grupeve të interesit", Tiranë, 2010.

Zakaria F., "E ardhmja e lirisë. Demokracia joliberale brenda dhe jashtë vendit", Instituti i Dialogut dhe Komunikimit, Tiranë, 2008.

Greenwood J., Interest Representation in the European Union, Palgrave Macmillian UK, 2003, 2007.

Wallace H., \& Pollack A. M. \& Young R. A., "Policy-Making in the Europian Union", Oxford University Press, 2010.

Raffaella Coletti dhe José Luis Rhi-Sausi, "Paradiplomazia e Politica Estera nell'Unione Europea", Roma, 2010, http: //www.cespi.it MP/DOC310\%20Paradiplomazia\%20Coletti_RhiSausi.pdf. dt.22.02.2014.

Boucher S., Royo M., Lamy P., LesThink-tanks: Cerveaux de la Guerredes/dées, éditions Le Félin, 2006.

Coen, D., The impact of the EU on the trade union movement in: Balme, R. et al., 2002.

Charrad K., Lobbying the European Union, WestfälischeWilhelms-UniversitätMünster,2004, http://nez.unimuenster.de/download ICharrad Literaturbericht_Lobbying mit_Deckblatt.pdf, dt. 24.09.2014

Bennardo P., Farella A., Oretano M., Savazzi E., Poletti A., Di Staso P., L'attività di lobbying nell'Unione Europea, 2010, http://www.ilchiostro.org/wp-content/uploads/2011/02/Ricerca_UE_a.a.09.101.pdf, dt.24.09.2014.

Lehmann W., \& Bosche L., Lobbying in the Europian Union: Current Rules and Practices, European Parliament, Directorate-General for Research, Working Paper, Luxembourg, European Parliament, 2003.

Christine Mahoney, "Lobbying Success in the United States and the European Union", Cambridge University Press, 2007. 19.02.2014, Available online at: http://faculty.maxwell.syr.edu/chmahone/Mahoney_JPP_2007.pdf 
Piero Mastroberardino, Gemma Carolillo, "Una disamina concettuale del termine lobby", Università degli Studi di Foggia, Quaderno n. 9/2006, http://81.174.35.131/laboratorioimpresa/public/upload/comuni/doc/MastroberardinoCarolillo-Quaderno\%20Dipartimento\%2092006.pdf.

http://www.globalpolicy.org/ngos/ngos-and-internationalregional-institutions/ngos-and-the-european-union.html; http://www.epha.org/IMG/ppt/Lobbying_EU_NGOs_20051031.ppt\#256,1,European PublicHealth Alliance; dt.24.09.2014. http://www.euractiv.com/en/pa/changing-face-european-think-tanks/article-142652; dt.24.09.2014. 